\title{
Percutaneous Cholecystostomy as a Step or Final Treatment for Acute Cholecystitis
}

\author{
Akut Kolesistit Tedavisinde Perkütan Kolesistostomi Bir Basamak Mı? Yoksa \\ Nihai Bir Tedavi Mi?
}

\author{
(D) Alpen Yahya Gümüşoğlu1 , (D) Hamit Ahmet Kabuli¹, (D) Aysun Erbahçeci Salık², (D) Çağlayan Çakır³, \\ (D) Seymur Abdullayev", (D) Kıvanç Derya Peker ${ }^{5}$, (D) Mehmet Karabulut ${ }^{1}$, (D) Gökhan Tolga Adaş ${ }^{1}$ \\ ${ }^{1}$ University of Health Sciences Turkey, Bakırköy Dr. Sadi Konuk Training and Research Hospital, Clinic of General Surgery, Istanbul, Turkey \\ ${ }^{2}$ Linköping University Hospital, Clinic of Radiology, Linköping, Sweden \\ ${ }^{3}$ University of Health Sciences Turkey, Bakırköy Dr. Sadi Konuk Training and Research Hospital, Clinic of Radiology, Istanbul, Turkey \\ ${ }^{4}$ Doğa Hospital, Clinic of General Surgery, Istanbul, Turkey \\ ${ }^{5}$ University of Health Sciences Turkey, Başaksehir Çam and Sakura Training and Research Hospital, Clinic of General Surgery, Istanbul, Turkey
}

\begin{abstract}
Objective: This study aimed to investigate the effectiveness of percutaneous cholecystostomy (PC) as a step treatment in patients who underwent PC for acute cholecystitis.

Methods: Data of 248 patients who underwent PC for acute cholecystitis between January 2015 and December 2019 were retrospectively analyzed. All patients who underwent PC were evaluated for a distal transition by cholangiography taken by the interventional radiology department in the third week after discharge. In addition, all patients were re-evaluated by the anesthesia department. Patients were retrospectively evaluated in terms of age, gender, American Society of Anesthesiologists physical status (ASA-PS) class, surgical procedure, complications after PC, and termination of PC.

Results: A total of 231 patients were included in the study. The mean age of patients was 68.6 (minimum-maximum: 32-92 years) and the male/ female ratio was 1.04 . The anesthesia evaluation of the patients categorized 44 patients (19.05\%) as ASA-PS class I-II and 187 (80.95\%) as ASAPS III-IV. A total of 17 (7.35\%) patients died in the 30-day follow-up period. The examination of the remaining patient revealed that PC was used as a step treatment in the transition to elective cholecystostomy in $106(45.8 \%)$ patients, whereas $108(50.4 \%)$ had it as a final treatment method since an operation is impossible. The median follow-up period in these patients was 2.6 years. Recurrent cholecystitis developed in 14 (12.96\%) patients in the group who underwent PC.
\end{abstract}

Conclusion: PC should be noted as an alternative step treatment method for acute cholecystitis but maybe a final treatment option in patients with high comorbidity.

Keywords: Percutaneous cholecystostomy, acute cholecystitis, ASA-PS

\section{öz}

Amaç: Bu çalışmada akut kolesistit tanısı ile perkütan kolesistostomi uygulanan hastaların verileri incelenerek yüksek riskli hastalarda perkütan kolesistostomi tedavisinin sonuçlarını araştırmayı hedefledik.

Gereç ve Yöntem: Bu çalışmada Ocak 2015-Aralık 2019 tarihleri arasında akut kolesistit nedeniyle perkütan kolesistostomi uygulanan 248 hastanın hastaların verileri retrospektif olarak değerlendirildi. Perkütan kolesistostomi uygulanan tüm hastalar taburculuk sonrası üçüncü haftada girişimsel radyoloji tarafından çekilen kolanjiyografi ile distale geçiş açısından değerlendirildi, aynı zamanda tüm hastalar yeniden anestezi tarafından değerlendirildi. Hastaların yaş, cinsiyet, Amerikan Anestezistler Derneği'nin fiziksel durumu (ASA-PS) class, yapılan cerrahi işlem, perkütan kolesistostomi sonrası gelişen komplikasyonlar ve perkütan kolesistostomi sonlandırılma durumları retrospektif olarak değerlendirildi.

Bulgular: Toplam 231 hasta çalışmaya dahil edildi. Hastalarda ortalama yaş 68,6 (minimum-maksimum: 32-92/yıl), erkek/kadın oranı: 1,04 idi. Kırk dört hastanın anestezi değerlendirilmesi $(\% 19,05)$ ASA-PS sınıf I-II, $187(\% 80,95)$ hastanın ise ASA-PS III-IV olarak saptanmıştır. Hastaların

Address for Correspondence: Alpen Yahya Gümüşoğlu, University of Health Sciences Turkey, Bakırköy Dr. Sadi Konuk Training and Research Hospital, Clinic of General Surgery, Istanbul, Turkey

Phone: +90 5353078391 E-mail: alpenygumus@hotmail.com ORCID ID: orcid.org/0000-0001-5378-9074

Cite as: Gümüşoğlu AY, Kabuli HA, Erbahçeci Salık A, Çakır Ç, Abdullayev A, Peker KD, Karabulut M, Adaş GT. Percutaneous Cholecystostomy as a Step or Final Treatment for Acute Cholecystitis. Med J Bakirkoy 2021;17:354-358

Received: 28.08.2021

Accepted: 11.10.2021 
30 günlük takibinde $17(\% 7,35)$ hastada mortalite izlenmiştir. Geriye kalan hastalar incelendiğinde $106(\% 45,8)$ hastada perkütan kolesistostomi elektif kolesistostomiye geçişte basamak tedavisi olarak yer alırken, $108(\% 50,4)$ hasta da cerrahi uygulanamadığından nihai bir tedavi yöntemi olarak kullanılmıştır. Bu hastalarda medyan takip süresi 2,6 yıldır. Perkütan kolesistostomi ile tedavi edilen grupta 14 (\%12,96) olguda rekürren kolesistit atağı gelişdi.

Sonuç: Perkütan kolesistostomi, akut kolesistitte alternatif olarak basamak amaçlı tedavi yöntemi olmakla beraber komorbiditesi yüksek hastalarda nihai bir tedavi seçeneği olabileceği bilinmelidir.

Anahtar Kelimeler: Perkütan kolesistotomi, akut kolesistit, ASA-PS

\section{INTRODUCTION}

Acute cholecystitis is an emergency that is seen in $20 \%$ of patients with gallstone disease $(1,2)$. The percutaneous cholecystostomy (PC) can be applied as a step treatment to prepare patients with high comorbidity for laparoscopic cholecystectomy (3). Studies are claiming that PC is a final treatment method (4). However, consensus on this issue is unclear.

This study aimed to determine the effectiveness of PC as a step treatment or a final treatment method by retrospectively evaluating the cases that were treated with PC in our clinic.

\section{METHODS}

In this study, data of 248 patients, who underwent PC with acute cholecystitis diagnosis between January 2015 and December 2019, were retrospectively analyzed. Patients who underwent PC due to gallbladder perforation were excluded from the study. A total of 17 patients, whose clinical and demographic data were missing, were excluded from the study. Consent was obtained from all patients who participated in the study. This study was approved by the University of Health Sciences Turkey, Bakırköy Dr. Sadi Konuk Training and Research Hospital, Ethics Committee (number: 2020-14-10 date: 06.07.2020).

A treatment approach was applied to patients with acute cholecystitis within certain study protocols since a hepatopancreatobiliary surgery unit has been available in our clinic since 2013. Therefore, all patients presenting with acute cholecystitis underwent early laparoscopic cholecystectomy under the Tokyo 18/13 Guidelines. The Tokyo Guidelines were adopted for the classification of violence for acute cholecystitis diagnosis (5). The anesthesia risk was determined by the anesthesia department before the surgery for patients with high comorbidities according to the American Society of Anesthesiologists physical status classification (ASA-PS) (6). According to the Tokyo guidelines, percutaneous cholecystectomy treatment was applied to the group with severity grades 2 and 3 and a high risk of anesthesia (ASA-PS III-IV). The biliary trees of all patients who underwent PC are evaluated by cholangiography taken by the interventional radiology department in the third week after discharge. After the sixth week, laparoscopic cholecystectomy was applied to the patients, which was re-evaluated by the anesthesia department and had no contraindications for surgery. The ASA-PSIV patient group with high anesthesia risk was grouped into two. As a result of cholangiography, the percutaneous catheter was withdrawn in the group with a cystic duct open distal transition, whereas in the group with symptoms with no distal transition and closed catheter, cholecystostomy catheter revision was performed at 3-month intervals (Figure 1). The patients' age, gender, ASA scores, surgical procedures, complications after PC, and PC terminations or revisions were retrospectively evaluated.

\section{PC Method and Follow-up}

Diagnosis of acute cholecystitis was confirmed by ultrasonography (US) and/or computed tomography. All procedures were performed with US guidance by a dedicated interventional radiologist under standard sterile conditions with local anesthesia and intravenous sedation. Most are performed in the interventional radiology unit, but procedures of 7 patients were performed in the intensive care unit due to unstable vital signs. The transhepatic approach was preferred for all the procedures and the gallbladder was always punctured using the Seldinger technique. Access to the gallbladder was confirmed by bile aspiration and an 8-12 Fr pigtail catheter was placed in the gallbladder lumen. Procedures were completed after confirmation of the pigtail loop of the catheters in the gall bladder lumen by the US. After the procedure, catheters were sutured to the skin and placed on gravity drainage. After 3 weeks of follow-up, transcatheter cholangiography (TC) was performed to assess the patency of the cystic and common bile ducts and the position of the catheter. When the cystic duct patency and tract maturation were confirmed by TC and the patient was asymptomatic, the catheters were withdrawn. Contrarily, if a patent cystic canal could not be observed, patients were followed up for 2 more weeks and the TC was performed again after 2 weeks. Within 2 weeks interval, patients were evaluated using the TC until cystic canal patency and tract maturation was verified up to 


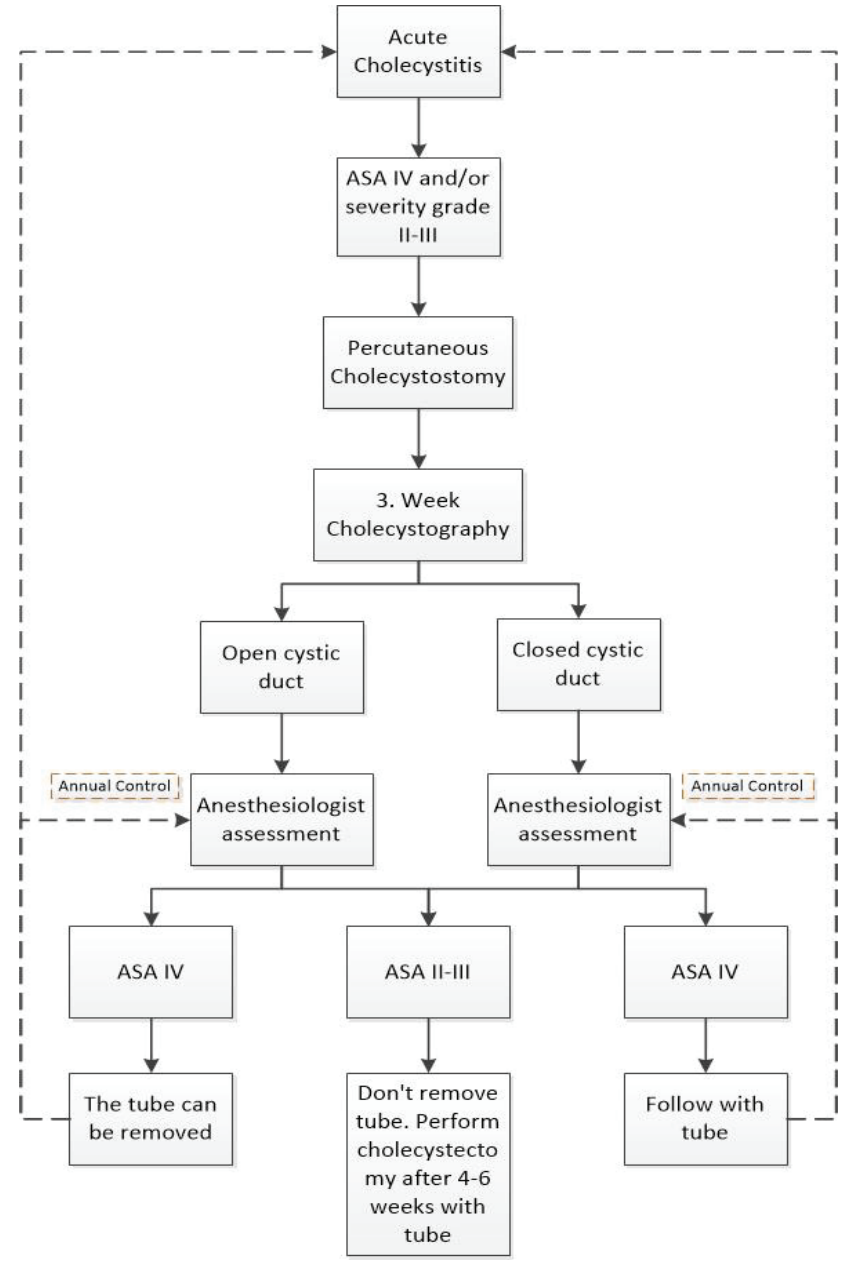

Figure 1. Our PC algorithm

PC: Percutaneous cholecystostomy, ASA: American Society of Anesthesiologists

3 months, and catheters were changed after 3 months. After 3 months of drainage, the catheters were discontinued in patients with cystic ducts and they were followed 3 days when the patient was asymptomatic and well-tolerated 3 days with stopped drainage, then the catheters were withdrawn. In case of symptoms for 3 days follow-up, patients were followed with percutaneous catheters, and catheters were exchanged with 3 months interval.

\section{RESULTS}

Data from 248 patients were analyzed within the scope of the study. A total of 17 patients with missing data were excluded from the study. The mean age of patients was 68.6 (minimum-maximum: 32-92), and the male/female ratio was 1.04. The anesthesia evaluation categorized 44 patients (19.05\%) as ASA-PSI-II and 187 (80.95\%) as ASA-PS III-IV. Considering the severity classification of patients according to Tokyo 2018 guidelines, 144 patients were grade 2 and
87 patients were grade 3 . The technical success rate was $100 \%$ during the study period; however, the clinical success rate was $92.65 \%$, and septic signs and symptoms could not be resolved despite PC in 17 (7.35\%) patients who were hospitalized in the ICU. These patients died from severe sepsis during the 30-day follow-up period.

During the follow-up period, 101 patients underwent laparoscopic cholecystectomy and 5 patients underwent open cholecystectomy. The remaining 108 (50.46\%) patients were treated with the PC. The median follow-up period for these patients was 2.6 years. Recurrent cholecystitis occurred in 14 (12.96\%) patients. PC catheters could be withdrawn in 68 patients upon seeing a distal transition in the cystic canal. During the follow-up of the remaining 40 patients, the distal transition was seen in 21 patients in a 3-week follow-up in the first 3 months, or the PC catheters could be withdrawn since they were asymptomatic when the catheter was closed. In the remaining 19 patients, catheter changes were performed once in 13 patients, twice in 2 patients, three times in 1 patient, and four times in 3 patients at 3-month intervals.

The most frequent complications following the PC procedure were catheter replacement (1.73\%), catheter discontinued $(1.29 \%)$, bile leak (1.29\%), fistula to skin $(0.86 \%)$, abscess/ infection (0.86\%), and bleeding (1.73\%) (Table 1).

Table 1. Demographic information and complications

\begin{tabular}{ll}
\hline - Age, years, median (range) & $68.6(32-92)$ \\
\hline - Gender, n (\%) & \\
\hline - Females & $113(48.9 \%)$ \\
\hline - Males & $118(51.1 \%)$ \\
\hline Complication & $3(1.29 \%)$ \\
\hline - Bile leak & $4(1.73 \%)$ \\
\hline - Bleeding & $4(1.73 \%)$ \\
\hline - Catheter dislodgement, replaced & $3(1.29 \%)$ \\
\hline - Catheter dislodgement, discontinued & $2(0.86 \%)$ \\
\hline - Fistula to skin & $2(0.86 \%)$ \\
\hline - Abscess formation/infection &
\end{tabular}

\section{DISCUSSION}

Laparoscopic cholecystectomy is a successful and effective treatment method for acute cholecystitis. PC can be used as a step treatment for elective cholecystectomy in some cases (3). In addition, PC can be used as an alternative treatment method with low complication rates especially in patients with high surgical risk $(4,7)$. 
The current study performed PC as a step treatment in the transition to elective cholecystostomy in $45.8 \%$ of patients, whereas $50.4 \%$ of patients had it as final treatment since no surgery could be performed. PC was the final treatment method especially in patients with a high risk of anesthesia and not suitable for elective surgery. The study of Tolan et al. (4) revealed PC as the final treatment method with a rate of $57.5 \%$. Similar to the present study, PC was used as the ultimate treatment method in $55.9 \%$ of patients in the study by Pang et al. (7).

A total of 17 patients with critical septic findings in the intensive care unit did not respond to the PC and the postprocedure septic findings did not improve. Response to PC ranges from $56-100 \%$ in the literature (8-11). This ratio is better in the present study. It is considered that patients' poor treatment responses may be due to the presence of severe comorbidities and possible multiple foci of infection. Therefore, the gallbladder drainage may not be sufficient to rule out septic findings. In addition, acute cholecystitis diagnosis in this group of patients is often more difficult because of their severe concomitant systemic diseases.

Cholecystectomy was performed in 106 (45.8\%) patients who underwent percutaneous drainage, wherein 94 (88.6\%) underwent laparoscopic cholecystectomy and 7 (6.6\%) laparoscopic partial cholecystectomy, whereas 5 (4.7\%) underwent cholecystectomy with the transition to open. The study by Yeo et al. (12) performed cholecystectomy in $42(41 \%)$ patients. The conversion rate was $15 \%$ in the study, whereas 34 (81\%) patients underwent laparoscopic cholecystectomy.

In the present study, the rate of recurrence after PC was $12.96 \%$, whereas this rate was $22 \%$ in the study of Sanjay et al. (13). The study of Chang et al. (14) observed recurrent acute cholecystitis in 7 high-risk patients (11.7\%). The remaining patients (88.3\%) were successfully treated with PC alone. The study by Wang et al. (15) revealed a recurrence rate of $9.2 \%$ and suggested that the cause of recurrence was complicated cholecystitis and elevated white blood cell counts.

The literature stated that the average time for PC removal is $4-6$ weeks (16). In the present study, cholangiography evaluation was preferred in the third week in cases who underwent PC. Peroperative PC catheter was withdrawn in cases where cholecystectomy was planned, whereas in 68 cases who had a distal transition on cholangiography but could not be operated on due to high risk, the catheter was removed in the third week with the confidence given by cholecystostomy performed by the transhepatic way. However, due to the distal transition on cholangiography in 40 patients with high surgical risk, percutaneous catheter replacement was performed in these cases at 3-month intervals. Recurrent PC catheter replacement was reported to be applied in the study by Boules et al. (17). The study of Horn et al. (18) revealed that recurrence is more frequently observed in cases where the distal transition is not observed (21.1\% versus $36.7 \% ; p=0.037$ ). Therefore, catheter revision was followed in this high-risk group with no distal transition in cholangiography and symptoms in closely follow-up (18). In addition, PC catheters can be left in place in patients with calculous cholecystitis and poor life expectancy. The catheter in this patient group was preferred to be removed but was tried to be withdrawn safely if possible during followup. Three months later, when the catheter replacement was first planned, the catheter drainage was closed and patients were followed up for 3 days. During these 3 days, symptoms, US findings, and clinical signs were not observed, thus the catheters were withdrawn.

In the present study, PC was performed using the transhepatic method. The aim was to choose a method with a lower risk of bile leakage, peritonitis, and intra-abdominal organ injury, as well as easier catheter stabilization in the group of patients with high comorbidity. However, this method resulted in pneumothorax and bleeding more frequently than transperitoneal PC (19). In the 30-day follow-up of patients, a total of 17 (7.35\%) patients died. In addition, complication rates were compatible with the literature in terms of catheter replacement (1.73\%), catheter discontinuation (1.29\%), bile leak (1.29\%), fistula to skin (0.86\%) abscess/infection (0.86\%), and bleeding (1.73\%) (20).

In cases where a distal transition is not seen in the cholangiography, methods such as cystic duct percutaneous stent placement and gallstone removal with fluoroscopy can be used to prevent recurrence in cases where the catheter cannot be withdrawn. Our study excluded such cases can be considered a limiting feature. The retrospective design of the study is another feature that limits the study $(21,22)$.

\section{CONCLUSION}

In patients with high surgical risk in the treatment of acute cholecystitis, PC is seen as a final treatment method rather than a treatment step. However, further studies are needed to reduce the risk of recurrence.

\section{ETHICS}

Ethics Committee Approval: This study was approved by the University of Health Sciences Turkey, Bakırköy Dr. Sadi Konuk Training and Research Hospital, Ethics Committee (number: 2020-14-10 date: 06.07.2020). 
Informed Consent: Consent was obtained from all patients who participated in the study.

\section{Authorship Contributions}

Surgical and Medical Practices: A.Y.G., H.A.K., A.E.S., Ç.Ç., S.A., K.D.P., M.K., G.T.A., Concept: A.Y.G., H.A.K., K.D.P., Design: A.Y.G., H.A.K., Ç.Ç., Data Collection or Processing: A.Y.G., Ç.Ç., S.A., Analysis or Interpretation: A.Y.G., M.K., G.T.A., Literature Search: A.Y.G., H.A.K., A.E.S., M.K., Writing: A.Y.G., A.E.S., K.D.P.

Conflict of Interest: No conflict of interest was declared by the authors.

Financial Disclosure: The authors declared that this study received no financial support.

\section{REFERENCES}

1. Strasberg SM. Clinical practice. Acute calculous cholecystitis. N Engl J Med 2008;358:2804-11.

2. Keus F, Gooszen HG, van Laarhoven CJ. Open, small-incision, or laparoscopic cholecystectomy for patients with symptomatic cholecystolithiasis. An overview of Cochrane Hepato-Biliary Group reviews. Cochrane Database Syst Rev 2010;2010:CD008318.

3. Okamoto K, Suzuki K, Takada T, Strasberg SM, Asbun HJ, Endo I, et al. Tokyo Guidelines 2018: flowchart for the management of acute cholecystitis. J Hepatobiliary Pancreat Sci 2018;25:55-72.

4. Tolan HK, Semiz Oysu A, Başak F, Atak I, Özbağrıaçık M, Özpek A, et al. Percutaneous cholecystostomy: A curative treatment modality forelderly and high ASA score acute cholecystitis patients. Ulus Travma Acil Cerrahi Derg 2017;23:34-8.

5. Yokoe M, Hata J, Takada T, Strasberg SM, Asbun HJ, Wakabayashi G, et al. Tokyo Guidelines 2018: diagnostic criteria and severity grading of acute cholecystitis (with videos). J Hepatobiliary Pancreat Sci 2018;25:41-54.

6. ASA Physical Status Classification System. Last approved bythe ASA House of Delegates on October 15, 2014.

7. Pang KW, Tan $\mathrm{CH}$, Loh S, Chang KY, lyer SG, Madhavan K, et al. Outcomes of Percutaneous Cholecystostomy for Acute Cholecystitis. World J Surg 2016;40:2735-44.

8. Akhan O, Akinci D, Ozmen MN. Percutaneous cholecystostomy. Eur J Radiol 2002;43:229-36.

9. Boland GW, Lee MJ, Leung J, Mueller PR. Percutaneous cholecystostomy in critically ill patients: early response and final outcome in 82 patients. AJR Am J Roentgenol 1994;163:339-42.

10. Chopra S, Dodd GD 3rd, Mumbower AL, Chintapalli KN, Schwesinger WH, Sirinek KR, et al. Treatment of acute cholecystitis in non-critically ill patients at high surgical risk: comparison of clinical outcomes after gallbladder aspiration and after percutaneous cholecystostomy. AJR Am J Roentgenol 2001;176:1025-31.

11. Browning PD, McGahan JP, Gerscovich EO. Percutaneous cholecystostomy for suspected acute cholecystitis in the hospitalized patient. J Vasc Interv Radiol 1993;4:531-7; discussion 537-8.

12. Yeo CS, Tay WW, Low JK, Woon WW, Punamiya SJ, Shelat VG. Outcomes of percutaneous cholecystostomy and predictors of eventual cholecystectomy. J Hepatobiliary Pancreat Sci 2016;23:6573.

13. Sanjay P, Mittapalli D, Marioud A, White RD, Ram R, Alijani A. Clinical outcomes of a percutaneous cholecystostomy for acute cholecystitis: a multicentre analysis. HPB (Oxford) 2013;15:511-6.

14. Chang YR, Ahn YJ, Jang JY, Kang MJ, Kwon W, Jung WH, et al. Percutaneous cholecystostomy for acute cholecystitis in patients with high comorbidity and re-evaluation of treatment efficacy. Surgery 2014;155:615-22.

15. Wang $\mathrm{CH}, \mathrm{Wu} \mathrm{CY}$, Yang JC, Lien WC, Wang $\mathrm{HP}$, Liu $\mathrm{KL}$, et al. Long-Term Outcomes of Patients with Acute Cholecystitis after Successful Percutaneous Cholecystostomy Treatment and the Risk Factors for Recurrence: A Decade Experience at a Single Center. PLoS One 2016;11:e0148017.

16. Park JK, Yang JI, Wi JW, Park JK, Lee KH, Lee KT, et al. Longterm outcome and recurrence factors after percutaneous cholecystostomy as a definitive treatment for acute cholecystitis. J Gastroenterol Hepatol 2019;34:784-90.

17. Boules M, Haskins IN, Farias-Kovac M, Guerron AD, Schechtman $D$, Samotowka M, et al. What is the fate of the cholecystostomy tube following percutaneous cholecystostomy? Surg Endosc 2017;31:1707-12.

18. Horn T, Christensen SD, Kirkegård J, Larsen LP, Knudsen AR, Mortensen FV. Percutaneous cholecystostomy is an effective treatment option for acute calculous cholecystitis: a 10-year experience. HPB (Oxford) 2015;17:326-31.

19. Little MW, Briggs JH, Tapping CR, Bratby MJ, Anthony S, PhillipsHughes J, et al. Percutaneous cholecystostomy: the radiologist's role in treating acute cholecystitis. Clin Radiol 2013;68:654-60.

20. Stanek A, Dohan A, Barkun J, Barkun A, Reinhold C, Valenti D, et al. Percutaneous cholecystostomy: A simple bridge to surgery or an alternative option for the management of acute cholecystitis? Am J Surg 2018;216:595-603.

21. Comin JM, Cade RJ, Little AF. Percutaneous cystic duct stent placement in the treatment of acute cholecystitis. J Med Imaging Radiat Oncol 2010;54:457-61.

22. Kim YH, Kim YJ, Shin TB. Fluoroscopy-guided percutaneous gallstone removal using a 12-Fr sheath in high-risk surgical patients with acute cholecystitis. Korean J Radiol 2011;12:210-5. 